\title{
DAMPAK KOMUNIKASI MASSA TERHADAP PERUBAHAN POLA KOMUNIKASI MASYARAKAT
}

\author{
Oleh: F.Winami \\ francisca_winarni@uny.ac.id
}

\section{Abstrak}

Komunikasi merupakan sarana penyebartuasan benta pengetahuan, pikiran-pikiran, nilai-nilai dan sikap hidup, kepercayaan dan lain-lainnya. Cara penyebarluasan yang dilakukan dengan menggunakan media massa dan menjangkau khalayak yang tidak dapat diketahui jumlahnya disebut komunikasi massa. Adapun fungsi komunikasi adalah sebagai : fungsi edukasi, fungsi persuasi, fungsi penerangan, dan fungsi hiburan. Peranan komunikasi dalam upaya meningkatkan kesejahteraan masyarakat perlu dikembangkan, sedangkan peranan yang menimbulkan dampak negatip pertu upaya pemecahan yang didasarkan suatu penelitian yang serius, apakah dampak yang ditimbulkan tersebut secara langsung atau secara tidak langsung agar dapat memecahkan permasalahan yang sebenamya dihadapi oleh masyarakat. Kebijakan yang diambil temadap upaya pencegahan dampak negatip pola konsumtif masyarakat, baik materi maupun pelaksanaannya harus sinkron atau terkoordinasikan antar pelaku-pelaku yang berkaitan dengan permasalahan tersebut yakni pihak produsen, pemerintah dan lembaga konsumen.

\section{Pendahuluan}

Perkembangan, perubahan, dan gejolak intemasional dewasa ini ditandai oleh gejala baru, yaitu globalisasi. Globalisasi yang didorong kemajuan pesat di bidang teknologi, terutama teknologi komunikasi menyebabkan semakin derasnya arus informasi dengan segala dampaknya baik positif maupun negatif.

Teknologi memang sangat bermanfaat bagi manusia dalam usaha memperbaiki taraf hidup dan bahkan dipertukan guna meningkatkan kesejahteraannya. Namun dalam hal ini manusia harus tahu dan mampu mendudukan pada proporsi yang wajar bagi teknologi dalam konteks kehidupan manusia secara keseluruhan, yaitu sebagai sarana hidup dan bukan sebagai tujuan bagi manusia.

Komunikasi dianggap sebagai salah satu faktor yang amat penting dan seringkali menentukan terhadap sukses atau tidaknya misi pemba- 
ngunan dan pengembangan sosial masyarkat. Ahli-ahli ilmu sosial pada umumnya sepakat bahwa salah satu ciri masyarakat modern adalah berkembangnya komunikasi dan sarana media massa yang memulai dan melanjutkan perubahan dari masyarakat tradisional (Alex Inkeles Amir Karamoy, 1974:37).

Sebagai alat untuk menyampaikan pesan, idea, gagasan, sebagai alat pendidikan maupun sarana hiburan, komunikasi nampaknya telah mendapatkan konotasi positif sebagai salah satu pembaharu dalam menuju perkembangan dan kemajuan. Pada pihak lain masih terasa benar kurangnya informasi pembahasan tentang peranan dan efek komunikasi terhadap masyarakat yang sebagian hidup berdasarkan pola tradisional yang kontras sekall dengan kehidupan masyarakat modem yang digambarkan dalam media komunikasi massa.

Tulisan ini bermaksud untuk mencoba membahas beberapa aspek komunikasi massa dan pengaruhnya terhadap pola konsumsi masyarakat, dan upaya-upaya untuk menangkal dampak negatif pengaruh komunikasi massa terhadap pola komsumsi masyarakat.

\section{Komunikasi dan Pembangunan} Masyarakat

Peranan komunikasi yang didukung oleh teknologi modem dalam perkembangan masyarakat dikemukakan oleh Lemer dalam Budhisantosa (1980:75) telah mampu menciptakan suasana yang melahirkan induvidu yang berkepribadian mobile yang justru diperlukan dalam masyarakat yang sedang membangun. Dengan adanya penyebaran informasi menurut D. Apter dalam Budi Santosa (ibio) akan menimbulkan kontak-kontak kebudayaan yang menjurus pada perubahan sikap masyarakat untuk meninggalkan pola-pola yang usang dan menggantikannya dengan yang baru.

Kemajuan teknologi di bidang komunikasi juga dirasakan manfaatnya di Indonesia. Perluasan jaringan komonikasi modem, dimaksudkan untuk meratakan pesanpesan pembangunan sampai ke pelosok tanah air. Daya tarik dan kemampuan media massa khususnya televisi dalam menyebarkan pesan lisan dan bergambar itu tidak diragukan lagi. Akan tetapi efektivitas informasi yang disampaikan untuk mencapai sasaran pembangunan nasional yang pada hakekatnya pembangunan manusia seutuhnya dan pembangunan seluruh masyarakat, dengan aneka ragam latar belakang sosial budaya memerlukan penelitian secara khusus. Dalam beberapa bahasan dapat ditemui beberapa pendapat bahwa media komunikasi massa juga turut mendorong perubahan perilaku konsumsi masyarakat. 
Pola konsumsi masyarakat dapat menjadi petunjuk yang kuat bagi perkembangan suatu masyarakat. Hal tersebut sesuai dengan pendapat Veblen yang mengatakan bahwa "tingkat kemakmuran masyarakat dapat dilihat dari tingkat conspicous consumption lapisan terbesar masyarakat " (Veblen dalam Andre, 1990:1). Perkembangan ekonomi dan tingkat kesejahteraan sosial di negara-negara berkembang sangat dipengaruhi oleh kehidupan ekonomi kota-kota besar yang berfungsi sebagai pusat pembangunan ekonomi dan modemisasi masyarakat. Oleh karena itu pola konsumsi masyarakat kota bukan sekedar berfungsi sebagai cermin kondisi sosial ekonomi masyarkat yang bersangkutan, tetapi juga menjadi tenaga penggerak dari kehidupan ekonomi dan dinamika sosial masyarakat secara keseluruhan.

Gejala konsumtif sebagaimana gerakan-gerakan sosial yang lain dalam masyarkat, pada umumnya dikaitkan dengan media komunikasi massa yang berkembang dalam masyarkat (Lerner dan Schramm, 1978:103-125). Menurut mereka, media massa dapat secara efektif dan efisien dimanfaatkan untuk mempromosikan pemasaran produk -produk banu (industri).

Promosi produk-produk baru dapat mendorong pertumbuhan ekonomi dan pengembangan industri. Namun promosi yang berle- bihan dapat menimbulkan dampak negatif yang merusak tatanan masyarkat. Meningkatnya konsumsi berbagai jenis produk yang dipasarkan negara-negara industri, dapat merugikan masa depan pembangunan jangka panjang negaranegara yang berkembang. Gaya konsumsi yang secara gencar dipromosikan oleh media massa akan melumpuhkan niat dan tekad masyarakat untuk menabung, timbulnya kehidupan pola baru yang berorientasi ke barat, dan memudarnya budaya Pancasila dalam kehidupan sehari-hari yang pada akhirnya menimbulkan kerawanan sosial yang bisa membahayakan stabilitas nasional. Keadaan yang. demikian yang merupakan tantangan kita dalam mengupayakan penangkalnya agar perkembangan media massa dapat lebih meningkatkan pencapaian tujuan nasional daripada dampak negatif yang ditimbulkan terhadap pola konsumsi masyarkat.

\section{Pola Konsumsi Masyarakat Seba- gai Perubahan Sosial \\ Pola komsumtif masyarkat} menurut Bambang Irawan (1992:57) adalah salah satu jenis perubahan sosial yang terjadi di masyarakat. Perubahan dapat terjadi pada tingkat induvidu, sebagai hasil dari disfusi, adopsi, modernisasi, proses belajar atau sosialisasi pada diri induvidu maupun dalam kelompok masya- 
rakat. Penubahan pola konsumsi dapat dikelompokkan dalam tipe perubahan sosial yang disebabkan adanya kontak (contact change).

Perubahan karena kontak adalah perubahan yang sumber gagasannya berasal dari luar suatu sistem sosial, kemudian dikenalkan ke dalam sistem sosial tersebut. Perubahan ini dapat bersifat selektif istepi dapat juga diarahkan. Seclangkan perubahan yang terjadi yang sumber perubahannya berasal dari sistem sosial itu sendin disebut jerubahan imanen.

Perubahan melaiui kontak yang selektif dimaksudkan bila pengaruh-pengaruh dari luar tersebut diterima atau ditolak dengan melalui suatu proses pertimbangan untung ruginya melaksanakan pengaruh tersebut. Sedangkan perubahan dengan melalui kontak yang diarahkan (directed contact change), atau sering disebut sebagai perubahan yang direncanakan, adalah akibat dri luar yang dengan sengaja mengenalkan suatu gagasan dengan tujuan agar dilaksanakan sesuai perintah yang telah ditetapkan.

Berdasarkan uraian tersebut dapat dijelaskan pengertian pola konsumtif atau pola konsumsi masyarakat di luar kewajaran yang monjurus ke penilaian yang negatif tersebut adalah salah satu tipe perubahan sosial akibat suatu kontak yang terjadi baik secara selektif maupun diarahkan pada tingkat induvidu maupun pada kelompok masyarakat tertentu.

Teori komunikasi memberikan gambaran pemahaman tentang gejala komunikasi baik mengenai bagaimana prosesnya maupun efek atau akibat ysng ditumbuhkannya. Pengaruh komunikasi yang terjadi dalam masyarkat ditentukan oleh fungsi yang dijalankannya. Fungsi komunikasi menurut Ashadi Siregar (1989:2) ada empat, yaitu: 1. fungsi edukasi, 2. fungsi persuasi, 3. fungsi penerangan. dan 4. fungsi hiburan.

Fungsi edukasi kalau informasi yang diberikan dapat memberikan gambaran dalam jangka panjang ataupun jangka pendek tentang kehidupan yang lebih ideal baik secara sosial maupun kemanusiaan. Fungsi persuasi akan ditunjukkan dengan informasi yang mampu memberikan gambaran tentang apa yang sebaiknya dilakukan dalam berbagai pilihan keputusan. Fungsi penerangan ditunjukkan dengan kemampuan informasi yang dapat memberikan gambaran situasi aktual agar dapat menempatkan posisinya dalam lingkungan. Sedangkan fungsi terakhir adalah hiburan yang sifatnya rekreatif pada masyarakat.

Kebermaknaan peran komunikasi terhadap kehidupan masyarakat sangat tergantung pada seberapa jauh informasi yang sampai kepada masyarakat tersebut sesuai dengan fungsi yang dilaksanakan 
secara tepat. Adanya penyimpangan-penyimpangan pelaksanaan fungsi tersebut, atau penonjolanpenonjolan fungsi tertentu saja akan menimbulkan bias pemahaman masyarakat terhadap informasi yang diterima. Dengan tingkat pemahaman masyarakat yang relatif masih rendah dikarenakan tingkat pendidikan yang sebagian besar masih kurang memadai, maka dapat terjadi kecenderungan penerimaan pesan yang tanpa disertai pertimbangan yang rasional, atau tidak berdasarkan konteks kehidupan masyarakat yang sebenamya. Kita dapat memahami ba-gaimana informasi yang sampai kepada masyarakat berkaitan dengan pelaksanaan promosi produk suatu industri yang disiarkan lewat media massa,

Dari ke empat fungsi tersebut, dilakukan oleh berbagai media massa seperti surat kabar, majalah, radio pemerintah dan swasta, televisi pemerintah dan swasta, dan media sosial. Berbagai media tersebut menerpakan informasi kepada masyarakat. Namun apakah ke empat macam informasi itu dapat sampai kepada masyarakat, ini memerlukan penelitian yang serius. Selain itu yang perlu mendapatkan perhatian yakni akses masyarakat terhadap media, karena betapapun derasnya ans informasi dari media yang ada, tidak akan ada maknanya jika masyarakat rendah aksesnya terhadap media.
Informasi yang dijumpai dalam surat kabar, majalah boleh dikatakan kurang menyentuh masyarakat bila ditinjau tingkat persebarannya yang hanya berkisar di kota-kota besar. Kalaupun ada media di tempat desa isinya lebih merupakan alat implementasi kebijakan pemerintah. Dari kecepatan waktu penyampaian, dan tingkat kecepatan pemahaman masyarakat media massa ini kurang berperanan. Dengan demikian media elektronik sebaran cakupannya lebih luas baik wilayah maupun jumlah penerima informasinya. Daya tarik dari suara, gambar dan hiburan yang disampaikan lebih tinggi karena tidak memerlukan penggunaan kemampuan pembacaan yang tinggi. Namun yang perlu menjadi perhatian yakni fungsi sesungguhnya yang dilakukan oleh media elektronik ini kepada masya-rakat, karena hal tersebut yang akan menentukan kebermaknaan informasi ataupun pengaruh negatifnya terhadap masyarakat.

Para pendukung model pembangunan ekonomi pasar bebas, umumnya beranggapan bahwa peranan media massa swasta komersial yang didukung sistem periklanan sangat positif. Sebab dengan mengiklankan jenis-jenis produk yang dihasilkan dan dikonsumsi oleh masyarakat negara-negara maju, dipandang sebagai upaya untuk meningkatkan pola-pola produksi dan konsumsi di negara 
miskin. (Rostow, 1960:18-19) misalnya menegaskan bahwa kriteria utama untuk tahap puncak pembangunan nasional adalah terciptanya "konsumsi massa secara besarbesaran". Proses pembangunan mencapai tahap puncak itu dengan merangkul dan sekaligus menggerakkan proses pemekaran produksi secara swasembada dan perluasan konsumsi masyarakat, sehingga keduanya saling dorong mendorong. Di negara berkembang, proses semacam ini berarti menarik mayoritas penduduk cari sektor pertanian dan sektor marginal ke sektor industri kota sebagai tenaga kerja. Harapannya di dalam industri kota itulah mereka dapat dididik dan dilatih ketrampilan untuk mengerjakan berbagai produk baru di pabrikpabrik. Dengan demikian mereka juga mengembangkan kemampuannya untuk mengkonsumsi produkproduk tersebut.

Lewat media massa seseorang tradisional memperoleh pengalaman pengalaman baru dan mengenal adanya jenis-jenis gaya hidup baru. Proses perolehan pengalaman baru ini dapat dipandang sebagai hal yang positif, namun dengan kondisi masyarakat yang berada dalam masa transisi antara pengaruh budaya lama yang masih lekat sementara perkenalannya dengan budaya baru belum sepenuhnya dihayati maka akan membawa dampak bukannya perbaikan nasib kehidupan tetapi dapat menjurus pada kerawanan sosial.

Bagi negara-negara berkembang, dengan latar belakang tingkat pendidikan yang relatif rendah, dan tingkat ekonomi yang belum sejahtera, promosi yang dilakukan dengan segala hadiah-hadiahnya dapat lebih cepat menarik perhatian masyarakat dan hasilnya memang dapat meningkatkan produksi dan konsumsi, tetapi tidak berarti langsung pada peningkatan kualitas hidup sebagian masyarakat. Menurut Wells yang dikutip Andre (1990:7) budaya konsumtif, sering hanya merupakan akibat dari upaya perusahaan-perusahaan multinasional yang tiada henti-hentinya memperluas pasar bagi produkproduk olahannya, sepeti minuman, rokok, kosmetika, alat-alat dapur, perabotan, makanan kaleng, mobil pribadi, obat-obatan dan sebagainya.

Bila kita amati produk-produk tersebut tidak akan memenuhi kebutuhan rakyat banyak dan juga tidak mendorong produktivitas sebagian besar rakyat. Promosi yang tens menerus lewat media massa, terutama lewat iklan yang gencar dan bertubi-tubi, membawa dampak $k e$ tengah masyarakat bukan saja secara langsung berkaitan dengan produk-produk itu sendiri, melainkan juga dapat menciptakan iklim serakah, yakni nafsu konsumtif uang secara terus menerus dipupuk 
berdasarkan standar yang terus berubah-ubah sesuai dengan standar yang berlaku di negara industri maju. Iklim yang demikian menurut Fromm dapat melahirkan suatu fenomena psikologi baru yang dikenal dengan sebagai fenomena homo consumens, yakni nafsu lapar dan haus yang tak pemah terpuaskan oleh produk-produk konsumsi yang ada karena tak henti-hentinya dipupuk, dirangsang dan dihembushembuskan oleh iklan baru (Fromm dalam Adre, 1990:8). Unsur budaya konsumtif ini adalah nafsu/dorongan psikologis untuk secepatnya menikmati produk-produk baru.

Dalam kompleksitas kualitas dan kuantitas kebutuhan manusia, produsen kadang-kadang tidak sekedar menunjukkan apa dan dimana produk dapat diperoleh agar orang dapat memenuhi kebutuhannya. Tetapi lebih jauh dengan memanipulasi kecenderungan orang agar motivasi membeli tidak bertolak dari kebutuhan nyata, tetapi bertolak dari kebutuhan nyata, tetapi bertolak dari keinginan yang tidak rasional. Iklan secara gencar memaksakan produk yang tidak diperlukan, kurang menjamin tentang mutu produk-produk yang disodorkan, mendesakkan kebutuhan akan produk tanpa disertai alasan apaapa.

Dampak berupa pola konsumtif masyarakat tersebut dapat kita telusuri lebih lanjut selain disebab- kan dominasi onientasi produsen juga disebabkan pola kebijaksanaan pembangunan yang dianut oleh suatu negara. Dalam pembangunan dikenal model pertumbuhan GNP dan bersifat "top-down", strategi pemabangunan "tricle down", maka dalam lapangan komunikasi juga terdapat hal yang serupa. (Ashadi, 1989:4).

Komunikasi yang bertolak dań anutan paradigma "top-down" akan bersifat searah, lebih bertitik berat pada kepentingan atas. Dengan paradigma semacam ini dikenal model komunikasi hypodermik, yeng memandang khalayak sebagai sasaran yang pasif. Ini membawa implikasi informasi yang dominan dalam masyarakat lebih bersifat persuasif. Komunikasi dari paradigma ini bertolak dari anggapan bahwa segala informasi yang berasal dari atas lebih penting ketimbang informasi yang berkaitan dengan kehidupan masyarakat yang menjadi sasaran pembangunan.

Pesan persuasi yang bersifat searah dan "top-down", selamanya mengandung makna memiliki konteks di luar kehidupan langsung khalayak sasaran. Persuasi ekonomi misalnya, hanya memiliki konteks pada kepentingan produsen dalam menumbuhkan irasionalitas dalam memenuhi kebutuhannya. Pemenuhan kebutuhan yang tergantung pada produk dari produsen industri akhirnya menjadikan khalayak sasaran 
sebagai konsumen, dan akibatnya lebih lanjut masyarakat dapat kehilangan jati dirinya.

\section{Kebijakan Pembangunan dalam Meningkatkan Peran Komunikasi}

Sejalan dengan perubahan konsep pembangunan Rogers metihat peranan komunikasi dalam pembangunan juga berubah. Jika pada sebelumnya komunikasi dianggap sebagai kekuatan yang ampuh dalam pembangunan, pada sekitar tahun 70-an peranan komunikasi mulai berubah. Menurut Rogers peranan komunikasi dalam pembangunan sekarang harus merupakan "suatu proses yang memungkinkan komponen-komponen suatu sistem sosial atau sistem itu sendiri memperoleh dan bertukar informasi yang dibutuhkannya dengan pihak lain" (Rogers dalam Isbandiyah, 1990:32). Apa yang dikemukakan Rogers tersebut sejalan dengan pendapat Lionberger dan Gwin (Isbandiyah, ibid.) bahwa komunikasi adalah faktor penting dalam pembangunan, tetapi bukan faktor tunggal yang dapat melakukan perubahan.

Paradigma pembangunan terakhir yang berkembang dan diterapkan oleh negara-negara berkembang termasuk Indonesia adalah pembangunan yang berwawasan peningkatan kualitas manusia. Dalam konsep pembangunan ini peranan komunikasi berbeda dibandingkan dalam pendekatan pembangunan atas-bawah di masa lalu. Informasi berbagai hal dapat disampaikan kepada kelompok-kelompok di daerah melalui media massa sesuai dengan kebutuhan informasi kelompok tersebut. Dengan demikian peranan komunikasi massa dalam konsep pembangunan diri lebih permisif dibanding pendekatan dani atas bawah.

Seiring denagan meningkatnya pendidikan dan tingkat kesejahteraan sosial masyarakat, pola kebijakan pengembangan komunikasi massa harus bertitik tolak pada orientasi menjadikan masyarakat sebagai konsumen yang menyadari jati dirinya. Dengan pola orientasi ini masyarakat diharapkan perilaku kosumsinya bertolak dari kebutuhan yang rasional yakni dilandasi pengetahuan dan sikap atas kualitas produk dan relevansinya dengan kebutuhan bukan dengan keinginan.

Kebijakan tersebut dalam jangka pendek dapat ditempuh dengan pemberian pengetahuan tentang kualitas produk dan kepalsuan promosi yang mengecoh, dan perlindungan pemerintah terhadap konsumen yang dirugikan. Dalam jangka panjang dilakukan dengan menumbuhkan perilaku ekonomi yang rasional dalam kehidupan masyarakat, melalui pendidikan dan penanaman sikap moral pembangunan yang mencerminkan nilai moral Pancasila atau dikenal dengan pening- 
katan pembudayaan Pancasila dalam kehidupan bermasyarakat, berbangsa dan bemegara.

Kebijakan tersebut dilakukan secara terpadu antara pihak produsen, pemerintah dan lembaga konsumen sebagai lembaga swadaya masyarakat yang bergerak dalam perlindungan konsumen terhadap manipulasi dan metode promosi yang menyesatkan masyarakat.

Pada kenyataannya yang paling banyak menikmati apa yang dikemukakan media adalah mereka yang punya akses media yaitu kelompok sosial ekonomi tinggi. Untuk mengatasi hal tersebut strategi penyebaran komunikasi yang perlu dikembangkan antara lain: penciptaan dan pengembangan media komunikasi tradisional untuk menjangkau kelompok yang kurang diuntungkan. Penggunaan media rakyat dan saluran informasi yang interpersonal sehingga lebih memungkinkan adanya usaha penyesuaian diri dengan kebiasaan, nilainilai dari masyarakat dalam lingkup lokal sebagai pusat kegiatan pembangunan.

\section{Penutup}

Komunikasi mencakup semua cara untuk menyebarluaskan berita pengetahuan, pikiran-pikiran, nilainilai dan sikap hidup, kepercayaan dan lain-lainnya. Cara penyebartuasan yang dilakukan dengan meng- gunakan media disebut komunikasi massa.

Akibat secara langsung ataupun tidak langsung yang ditimbulkan oleh kemajuan teknologi komunikasi baik yang positip maupun yang negatip dapat dilihat dalam segala bentuk. Komunikasi yang positip dapat mendukung persatuan dan kesatuan bangsa, mempermudah pengambil-an keputusan dan memperlancar proses kegiatan organisasi. Komunikasi yang tidak mampu menumbuhkan perilaku positip masyarakat antara lain seperti perilaku konsumtif masyarakat.

Peranan komunikasi dalam upaya meningkatkan kesejahteraan masyarakat perlu dikembangkan, sedangkan peranan yang menimbutkan dampak negatip perlu upaya pemecahan yang didasarkan suatu penelitian yang serius, apakah dampak yang ditimbulkan tersebut secara langsung atau secara tidak langsung agar dapat memecahkan permasalahan yang sebenamya dihadapi oleh masyarakat.

Kebijakan yang diambil terhadap upaya pencegahan dampak negatip pola konsumtif masyarakat, baik materi maupun pelaksanaannya harus sinkron atau terkoordinasikan antar pelaku-pelaku yang berkaitan dengan permasalahan tersebut yakni pihak produsen, pemerintah dan lembaga konsumen. 


\section{Daftar Pustaka}

Abu Syuqqah, 'Abd at-Halim. 1997. Tahnir al-Marah fi 'Ashr alRisalah. Alih bahasa oleh Chairul Halim. Jakarta: Gema Insani Press. Cet. I. Jilid 2.

Amit Karamoy. 1974. "Beberapa Aspek dan Penganuh Komunikasi Temadap Pemuda di Kampung-Kampung Kota.". PRISMA. No. 3. Juni III. LP3ES : Jakarta.

Andre Hardjana. 1990. Penilaku Konsumtif Masyarakat Kota di Negara Berkembang. Seminar Nasional limu-fimu Sosial dan Konggres VI HIPIIS. tanggal 16-21 Juni 1990: Yogyakarta.

Ashadi Sireqar. 1989. Komunikasi Terhadap Penilaku Konsumen Pedesaan. Yayasan Lembaga Konsumen: Yogyakarta.

Bambang Irawan. 1992. Teori Komunikasi yang Relevan Bagi Studi di indonesia. Fisipol UGM : Yogyakarta.

Budhisantosa.S. 1980. "Televisi dan Masyarakat Pedesaan". PRISMA. No.3 Maret tahun IX LP3ES: Jakarta.

isbandiyah. 1991. Komunikasi Pembangunan di Negara-Negara Berkembang. Fisipol. UGM: Yogyakarta

Rostow,W.W. 1960. The Stage of Economic Growth: a Non Com- munist anifesto. Cambridge University Press: London.

Schramm. Wilbur dan D. Lemei. 1978. Communication and Change: The Last Ten Years and The Next. The University Press of Hawai: Honolulu.

\section{Biodata Penulis}

Dra. F. Winarni, M.Si. adalah staf pengajar pada Program Studi Pendidikan Administrasi Perkantoran Fakultas IImu Sosial Universitas Negeri Yogyakarta. 